\title{
The Occupiers and the Occupied: A Nexus of Memories
}

Christine de Matos

University of Wollongong

\section{Introduction}

In Ōe Kenzabur's The Silent Cry, the two protagonists, Jin and Mitsuburo, discuss conflicting memories of the Allied Occupation of Japan:

'Just after the defeat, when the occupation forces came in jeeps. Don't you remember? All the able-bodied folk ran off into the forest, leaving the old people and disabled behind in the valley. That's what I'm talking about.'

'But you're wrong, Jin', I said. 'I know, because I was in the valley when the first jeeps arrived. A GI gave me a can of asparagus, but the grown-ups didn't know whether it was something to eat or what it was, so in the end I left it in the teachers' room at the primary school.'

'No - they cleared out, the whole lot of them!' Jin insisted calmly.

Memory: contentious, volatile, selective, relative. Ōe's protagonists remember the coming of the Occupation troops in different ways, and yet memory can be used to enrich and to (con)test the historical record; to remind ourselves that historical events have both long- and short-term impacts upon the lives of human beings in nuanced ways. As LaCapra has written:

Memory is a crucial source for history and has complicated relations to documentary sources... Conversely, history serves to question and test memory in critical fashion and to specify what in it is empirically accurate or has a different, but still possibly significant, status. $^{2}$

This paper explores the 'different, but still possibly significant, status' of the memories of Australians who occupied Hiroshima Prefecture with the British Commonwealth Occupation Force (BCOF) from 1946 to 1952 and the Japanese who lived under Australian occupation.

\footnotetext{
${ }^{1}$ Ōe, The Silent Cry, pp. 163-164.

${ }^{2}$ Dominick LaCapra, cited in Molasky, The American Occupation of Japan and Okinawa, p. 4
} 


\section{Current Research Background: Hidden Histories of Occupation}

On my first visit to Japan in 1986, I fell in love - with the country, the people and the culture. That visit inspired me to further my education and learn more about Japan, and since that time I have been able to integrate my fascination with Japan into my career as an historian by engaging with the history of relations between Australia and Japan in the postwar era.

Whenever I visit Japan, there are always cultural misunderstandings or differences to negotiate. For instance, in 2004 I spent three months in Hiroshima as a Japan Foundation Fellow in order to conduct oral history interviews and collect documents for my current research. It was the first time I had conducted formal interviews outside Australia. I found the process to be rather like a miai meeting in a Tanizaki Jun'ichirō novel - that is, a meeting for arranging a marriage. I had to engage a 'go-between', someone known to me, to find and approach potential candidates and then 'broker' the interview. The 'go-between' was also present at the interview as facilitator and sometimes interpreter. I had been used to directly approaching potential interviewees and arranging the interview myself, so the slower process and loss of direct control took a little adjusting on my part. However, I was fortunate to have very competent and patient 'interview brokers'!

The interviews in Japan were part of the data collection for my current research project on the Allied Occupation of Japan. The Occupation is primarily remembered collectively as an American affair. Australia was a long-term, active participant in the Occupation, yet has not received a level of scholarly attention commensurate with that participation. My current research project is a social history that aims to help fill this gap by investigating the diverse direct and indirect interactions between Australians as occupiers and Japanese as the occupied in the Hiroshima Prefecture. In particular, it intends to analyse the intersections of gender, race and class in Occupation experiences and interactions.

The Allied Occupation of Japan began in 1945 and ended in 1952 (except in Okinawa). Australia's occupying forces arrived in early 1946 as a contingent of BCOF. The Australian base was in Hiro, while the BCOF headquarters was located in Kure. BCOF was comprised of Australian, New Zealand, British and British-Indian troops, but was always commanded by an Australian. At the height of its presence in 1946, Australia provided almost 12,000 troops to BCOF, and 45,000 Australians participated over the course of the Occupation. Australia also contributed diplomatically to the Occupation: an Australian represented the British Commonwealth on the advisory body based in Tokyo, the Allied Council for Japan; an Australian presided over the International Military Tribunal of the Far East; and a separate Australian delegation participated in the policymaking body for the Occupation based in Washington DC, the Far Eastern Commission. Additionally, many men in the forces were joined by their families, and Australian 
women also came to Japan as nurses (Australian Army Nursing Service), as other medical practitioners (Australian Army Medical Women's Service) or as volunteers (for example, the YWCA or Red Cross). Also present were missionaries, reporters, intellectuals and travellers. An Australian community was transplanted in Japan, such as that at Nijimura, complete with homes, shops and schools, existing separate from, yet interacting with, the Japanese. This is a distinct phenomenon in Australian military occupation and peace-keeping history.

An essential part of the research project is the collection of memories of occupation from Australians and Japanese. The remainder of this paper shares some of the events from, interpretations of and even epiphanies about the Occupation from oral history interviews, novels and the official documentary record.

\section{Remembered Moments: The Good, The Bad and The Poignant}

\section{Japanese}

Some of the memories shared with me by Japanese men reflect the darker side of the Occupation. Matsuno Seiso worked for the BCOF watercraft squadron as a crewmember on a small boat. The coxswain of the boat was always an Australian soldier. Matsuno recalls that one of the main barriers between Australians and Japanese was language and language, especially in terms of the Occupation, equalled power. Frustrations over communication, exacerbated by orientalist attitudes and the then emerging stories of mistreatment of Australian POWs by Japanese soldiers, often resulted in the abuse of Japanese labourers by Australian soldiers, especially in the early part of the Occupation. However, those who could speak the occupier's language - thus able to reclaim some level of agency and negotiated power - usually fared a little better. As Matsuno relates:

At first, the other workers couldn't understand English ... so the Australian soldiers were frustrated. They often got mad at the Japanese people, yelling at them. At the same time, soldiers had family members who were POWs ... so they really hated the Japanese. In my case, I could communicate a little bit, so we could understand each other. Most of them [the Australians] were nice people.

The coxswain ... was looking at the Japanese people like: 'what on earth is that?' That was when he was first interacting with the Japanese. At first they were staring at us but when we spoke for two or three days that all changed.

[One coxswain] didn't understand Japanese, although he invited the Japanese people's children or friends to come on board. They couldn't understand him so they were cursed at a lot. He kicked them too because he was frustrated at the language barrier. As ... I understand English ... he never yelled at me. ${ }^{3}$

\footnotetext{
${ }^{3}$ Matsuno interview 2004.
} 
Mistreatment of Japanese workers is a consistent theme in Australian novels written about the Occupation, including T.A.G. Hungerford's Sowers of the Wind and Hal Porter's A Handful of Pennies, thus mirroring Matsuno's personal experiences. One of Porter's characters, Dugald, regularly kicks his Japanese gardener and housegirl and does little to hide his hatred of the Japanese. ${ }^{4}$ Hungerford's characters regularly define the conflicting tensions between and within Australian Occupation soldiers over how to treat the Japanese people. One character, Colonel Lefevre, after arriving on the Kure wharf and finding some Japanese labourers huddled around a fire on a cold night, proceeds to literally kick out both the labourers and their fire. On being challenged over this behaviour by two other soldiers of varying ranks, he responds: 'My apologies ... I merely thought that, after the way they treated Australians and others, that to give these damned Japanese fires while they work seemed a little - ah - soft.' ${ }^{5}$ While these are fictional accounts, they marry well with the memories of Japanese workers such as Matsuno, and both Porter and Hungerford participated in the Occupation, thus their stories have emerged from direct observations. ${ }^{6}$ These experiences are also supported by the archival record. For instance, a complaint was made against an Australian soldier, apparently drunk and held as a POW by the Japanese during the Asia-Pacific War, who had struck a Japanese man working for the Occupation forces as a 'canteen boy' across the face for drinking sugared tea. ${ }^{7}$ While the soldier later apologised, his behaviour was part of a consistent pattern. A female Japanese working as a waitress at the ANZAC Club in Kure was kicked by the same soldier, and finally quit her job after he gave her caustic soda with which to clean, thus making the skin peel from her hands. ${ }^{8}$

Many Japanese contextualised the actions of some Australian soldiers within the White Australia Policy. As well as witnessing the mistreatment of their own, some Japanese saw similar actions conducted towards other Allied soldiers, especially Indian (who were part of the BRINDIV component of BCOF). Okamoto Kazuhiko remembers seeing Australian soldiers 'teasing the Gurkha soldiers right in front of us.' He then simulated their actions - the Australians were pretending to slit the Gurkha soldiers' throats. ${ }^{9}$

There are also more positive memories, especially from those Japanese who were able to forge closer relationships with Occupation soldiers due to their higher Englishlanguage skills. Yoshida Takayoshi, who worked as an interpreter for BCOF after returning to Japan in 1947 from the Soviet Union and China, where he had been taken as a POW, remembers the kindness of one sergeant who often flouted the rules and borrowed English-language books for him to read from the BCOF library (meant for the Force,

\footnotetext{
${ }^{4}$ Porter, A Handful of Pennies, passim.

${ }^{5}$ Hungerford, Sowers of the Wind, p. 59.

${ }^{6}$ Both Hungerford and Porter participated in the Occupation, Hungerford in intelligence and Porter as a teacher in a BCOF dependents' school. Considering the level of anti-Japanese sentiment that still existed in postwar Australian society, the medium of the novel may have been a less contentious way to air criticism of Australia's military role/behaviour during the Occupation. Additionally, Hungerford's later autobiographical work A Knockabout with a Slouch Hat refers to Occupation incidents that closely resemble some of those in his novel. ${ }^{7}$ AWM114, 423/10/56 'Statement by Takemoto Masao', 8 September 1949 and 'Statement by Motoki Sukekazu', 7 September 1949.

${ }^{8}$ AWM114, 423/10/56 'Reason for Resignation', 5 September 1949.

${ }^{9}$ Okamoto interview 2004.
} 
not the Japanese). The two kept in contact for a short while after the sergeant returned to Australia. Another experience of Yoshida highlights the very affectionate relationship that developed between some Australians and Japanese. Yoshida relayed a story to me that has haunts him to this day. An Australian warrant officer, like many Australian soldiers, fell in love with his 'housegirl', ${ }^{10}$ a lady from Yoshiura. ${ }^{11}$ Yoshida acted as a go-between and translator for the two, as the warrant officer wanted to marry her. However there were two main obstacles to overcome: the lady was reluctant to marry a foreigner, and the warrant officer already had a wife in Australia.

Yoshida maintains that the warrant officer was 'sincere' in his feelings for the lady from Yoshiura. The officer returned to Australia, divorced his wife, and was planning to return to Japan to woo his Japanese love. Tragically, the officer was killed in a motor vehicle accident before, as Yoshida says, 'he was successful in his proposal.' ${ }^{12}$ I was personally touched by the sincerity of Yoshida's reaction to this story, and obvious distress at the tragic outcome - it demonstrated a personal affinity for this foreign soldier that has had a lasting effect on his life. The 'war brides' who did come to Australia, Japanese women who married Australian soldiers, are often seen as a vanguard of changed attitudes towards Japan in Australia and the beginning of the end of 'White Australia'.

Other Japanese had quite a different relationship with Australian soldiers due to their political affinities. Okamoto, a member of the Japanese Communist Party (JCP), allowed his home to be used by Australian soldiers who were associated with the Communist Party of Australia (CPA). These soldiers also gave Okamoto copies of CPA publications - 'I don't understand English so I sent them on to the party head office' - and monies to aid in the JCP's activities, such as running candidates in elections. ${ }^{13}$ Likewise, Watanabe Rikito, also a JCP member, remembers Australian soldiers waving red handkerchiefs in support at JCP public demonstrations and monetary contributions, but language was a constant barrier. When Australian soldiers dropped by the JCP office in Hiroshima, 'We basically sang L'Internationale together, shook hands, they gave us money, and then we parted. That was basically it.' ${ }^{14}$

There are also more comical stories arising from cultural differences. Isogame Haruo worked as a seaman in the BCOF water transportation squadron. One day when boarding a barge with co-workers and an Australian supervisor, they noticed:

a big octopus on the steps under the pier and we tried to catch it. But Sergeant Coplan [supervisor] got angry with us. He said it was the devil. I wondered why Australians disliked it. But it was a waste for a Japanese to let it go, so we took off our trousers and

\footnotetext{
10 'Housegirl' was the term Australians used to describe the domestic workers they were allocated. Males were referred to as 'houseboys'. These workers were generally paid by the Japanese government.

${ }^{11}$ Yoshiura is a part of the city of Kure.

${ }^{12}$ Yoshida interview 2004.

${ }^{13}$ Okamoto, op. cit.

${ }^{14}$ Watanabe interview 2004.
} 
caught it. We brought over the big octopus but Sergeant Coplan turned pale and ran away to the office. That was fun... The next day he asked us 'did you eat the octopus?' and we said 'yes.' Then he said 'you will all die...'15

'they all wore skirts, didn't they?'

The ubiquitous image of the occupier as American affects some memories of the Australian role in the Occupation. Japanese historiography, novels and film about the Occupation is replete with American, not BCOF, soldiers. In the memoirs of an industrial dispute in Hiroshima in 1949 in which Australian BCOF troops were involved, two participants, Shinmi Itoe and Watanbe Tamiko, both refer to the soldiers as 'American.' ${ }^{16}$ Lack of awareness is confirmed by a survey conducted by BCOF in the Hiroshima Prefecture city of Oura in 1947 that 'discovered that the townspeople did not know the nationality of the Occupation Force. ${ }^{17}$ While some Japanese were able to tell the Australian troops apart by their uniform, especially their distinctive slouch hat, others had more trouble. At least one of the Japanese interviewed thought that all the BCOF troops, including Australians, wore 'skirts' - the kilts of the Scottish members of BRINDIV.

\section{Australian}

On the Australian side, Douglas Helleur was a 'communist catcher. Helleur trained as a Japanese linguist in Australia at the end of the Asia-Pacific War, and was posted first to the Combined Services Detailed Interrogation Unit (CSDIC), a translating and interpreting unit, and later to a military government team. Helleur worked closely with Japanese police in helping to curb activities like the blackmarket (he once said he preferred working with the Japanese police to the Americans). Finally, he joined 36 Field Security, the BCOF intelligence group, and was involved in the interrogation of Japanese soldiers repatriating from the Soviet Union, especially to gain military information about the Soviet Union for the Americans. ${ }^{18}$

Although Australians worked closely with the Americans in the intelligence domain, they held quite different attitudes towards the possibility of anti-Occupation activities from the Japanese. Helleur stated that in Field Security, they were supposed to spend about 15-20 percent of their time 'looking at the Japan Communist Party', but the Americans 'spent most of their time on JCP matters. ${ }^{19}$ The following anecdote highlights the different attitudes towards communism and insurrection in Japan:

\footnotetext{
${ }^{15}$ Isogame interview 2004 .

${ }^{16}$ Watanabe et al, (eds), Hiroshima under Occupation, (senryōka no Hiroshima), pp. 157 \& 162-163.

${ }^{17}$ AWM52 8/2/33, 'BCOF Monthly Intelligence Review No. 20', p. 2.

${ }^{18}$ Helleur interview 1999.

${ }^{19}$ Helleur correspondence 16 May 1999.
} 
During 1948, unknown to the Japanese, there was internal mail censorship, and a letter was picked out which contained some information that indicated a Communist plan for a general strike in August 1948, and it would be followed in October by an armed rebellion. This frightened the Americans ... I very rarely carried a pistol all the time I was in Japan - I might have carried it half a dozen times - but I was coming home one night to my place in Field Security in Tottori and I was driving past the American, or the Allied, Military Government, and a bloke came rushing out with a carbine. It was an M30 and he said 'What guns have you got up the hill there?' 'I've got a 38 pistol and my colleague also has a 38 pistol.' He said: 'Here, you better have two of these, and he handed me two rifles with a couple of boxes of ammunition. So I said 'What's all that about?' and he said 'You'll know when you get home.' So I drove up the hill and five minutes later I walked in and said to my partner 'What's going on?' 'Oh', he said, 'the Yanks are jumping up and down about a possible general strike and it's going to be followed by an insurrection.' I said 'But the Japanese haven't got any guns!', and he said, 'Yeah we know. Only about twenty per cent of the police force were armed, and even they weren't allowed to carry a gun unless they had our permission. Anyway I said 'I've got two beautiful rifles in the jeep. We'll go down to the beach and try them out.' We eventually shot away all the American ammunition and returned the two empty rifles. ${ }^{20}$

The intercepted letter turned out to be from a Japanese male trying to impress his girlfriend.

Hugh Shackcloth's experiences working in Army Signals in BCOF reflect the metamorphosis that many Australians experienced after arriving in Japan - moving from seeing the Japanese as enemies to developing an affinity for Japanese people and culture - and in having to navigate cultural differences and misunderstandings. Shackcloth was involved in training Japanese specialists to convert to a single communication line based on the PMG system (Postmaster General - equivalent to Telstra today). He held many meetings with the Japanese, and one such experience is detailed below:

Instead of me talking and the interpreter translating, I used to get my speech ready and then I'd go through it with the interpreter, and then underneath the Japanese I'd have my phonetic version of Japanese and then I'd read that. On this day it was fairly lengthy and the Japanese were getting very edgy. I thought 'Well I don't know, I don't think I'm treading on anything here [causing offence],' and I finally said to the interpreter 'What's wrong with them, they're getting very nervous, edgy'. He said 'They badly need a smoke, you've been going for nearly an hour' and I said 'Well why don't they smoke?' He said 'They wouldn't dare unless you smoked.' I said 'Hell, I don't smoke.' So this is how we solved the problem: he passed me a cigarette and the lighter under the cover and I very ostentatiously lit it, and then said 'Dōzo Please please for me........' And I thought 'Good Lord, if that's what nicotine does thank God I don't smoke.' I learned afterwards that the first thing I did to start any conference was to light up, even though I put the cigarette in the ashtray and let it burn, but they were happy then. In general I liked the Japanese people, I got on very well with them. ${ }^{21}$

\footnotetext{
$\overline{{ }^{20} \text { Helleur interview, op. cit. }}$

${ }^{21}$ Shackcloth, op. cit.
} 
This transformation of wartime attitudes even occurred with former POWs, in contrast with the earlier example of the abusive Australian soldier. Joe was a POW in Thailand for three and a half years, and needed hospitalisation upon his return to Australia. He re-enlisted in the army at the end of the Occupation under a false name and went to Japan (most likely to participate in the Korean War). In a letter written to the nurse who took care of him while recovering from his POW ordeal, he conveyed his initial uncertainty when arriving in Japan, especially of not being able to look a Japanese in the face. However, 'This feeling only lasted a day or two... now I natter away and laugh and joke with them and don't feel at all unkindly towards them. ${ }^{22}$ While in the POW camp, Joe had picked up some of the Japanese language. When queried on his language ability by Japanese associates, he at first answered honestly. Their reactions are interesting: one looked startled, 'whipped off his cap bowed and said [very, very] sorry about 14 times in 14 seconds!'. Another simply went silent and was unable to continue to talk. Joe was most disconcerted by these reactions - he was not looking for sympathy or revenge - and from that moment told any Japanese he met that he had learnt the language from his brother who had spent four years in Japan. ${ }^{23}$

The Australians were part of an Occupation force that, ostensibly, was to 'democratise' Japan. What did this mean to the average soldier? As there was an implicit orientalist assumption within the victor's ideology - Australian, American or other allies - that their political, social, economic and cultural systems were superior to those of Japan, it was generally believed by Australian soldiers that 'showing them how we lived' constituted 'democratisation'. One of the Occupation aims was the emancipation of women but, leaving aside the often abusive physical or sexual behaviour of many soldiers towards Japanese women that absolutely violated and made hypocrisy of this aim, ${ }^{24}$ did Australian soldiers envisage a positive role for the force to play? Here is how Shackcloth viewed his role:

Not every Sunday but now and again, we went down to the village which was outside the walls and we found the ice cream man, the local Mr Whippy - it was ice ground up into a paper funnel and over that they poured raspberry or green or yellow or whatever the kid wanted in the way of flavour [kakigōri]. So this chap and I, we'd haggle with the vendor and we'd buy the lot, then we'd give him a few cigarettes and tell him to sit down over there out of the way. We blew the whistle and all the rest and got 'em round and all the boys lined up in front so we used to, with fiendish delight, put the boys at the back and we used to serve the girls first. Did those boys hate that ... what we were trying to do in our little way was 'Ladies First'. The expression on this chap's face when he was sitting there puffing on his cigarette that he normally couldn't afford and you could see him thinking: 'Really Australians are mad, they buy it and then they give it away, they're crazy!', and so perhaps we were. ${ }^{25}$

\footnotetext{
${ }^{22}$ Joe[full name withheld on request], letter 8 November 1952.

${ }^{23} \mathrm{Ibid}$.

${ }^{24}$ See Tanaka, Rape and War. Also read the Occupation novels by Hungerford and Porter.

${ }^{25}$ Shackcloth, op. cit.
} 
Shackcloth's understanding of his role, while absolutely sincere, had little to do with gender equality and more to do with particular social etiquettes that emphasised gender difference and reinforced women's role in the (idealised middle class) domestic sphere. This is also evident in other actions, such as taking the 'woman of the house', rather than the man, a small gift when invited into a Japanese family's home for a meal, to show appreciation 'to the hostess because in our country the hostess is the lady that runs the house and she's provided the entertainment and the tea and that... is our way of saying thank you to her. ${ }^{26}$

Occasionally, Australian soldiers had personal experiences where they questioned the legitimacy of their role in Japan and the 'superiority' of their own culture. Such epiphanies are sprinkled throughout the occupation novels. Porter's character Everard-Hopkins has the following discussion at the bar, and this extract from the novel questions the validity of the underlying orientalist assumptions of the aims of the Occupation:

'Democracy,' continued Everard-Hopkins and his whisky, 'is a Western foible ... ideas, you know, based on a defiant conceit we imagine is our freedom - politics based on, of all sands, religion! Oriental life is based on, shall we say, firmer sand ... oh yes, certainly firmer, on a philosophy, on a harmony of subordination, on those unwritten codes so much more logical than ethics typewritten in triplicate. How naïve of the West to disprove an Oriental divinity without proving a Western one, particularly here where a series of cataclysms had turned cynical even the most unworldly...

'But I am intensely, oh intensely, interested in onlooking at the results of a vanity which suggests by its purgings and reformations that the Seven Deadly Sins are better than the Eight Dusts of Anger, Selfishness, Covetousness, etcetera. Is thirteen a better unlucky number than the Oriental four, is it wiser to beckon palm-up as we do or palm-down as they do, is hanging more aesthetic than beheading? Do you understand what I infer? We are unable to prove, even to ourselves, that what we consider important is important, to us, let alone these...foreigners.27

In a telling phrase that even Everard-Hopkins was a victim of his culture's own orientalist discourse, Porter's companion goes on to correct him that 'Surely ... we are the foreigners. ${ }^{28}$

The following interview extract from Shackcloth reflects a similar, seminal moment of cultural questioning:

I'd stopped for lunch one day and looking across this valley I could see things moving up this hill, miles across. I got my field glasses out, and I could see legs underneath these trees going up, so I gave the glasses to an interpreter and said 'What's that?' He said,

\footnotetext{
${ }^{26} \mathrm{Ibid}$.

${ }^{27}$ Porter, op. cit., pp. 18-19.

${ }^{28} \mathrm{Ibid}$.
} 
'Oh, they're just putting the new trees in.' [When I asked about the process] they looked at me and they said 'Well, where would the animals and birds live if we cut all the trees?'

I sent my staff to work to follow back through when re-forestation started, ... and you how long to you think it was, four thousand years... We had been here [in Australia] one hundred and fifty years and we were down to twenty percent of our forests, the rest we'd cut and burnt and I thought then, we've got a lot to learn from these people ... It just used to leave me at times thinking, 'Good lord, we're backward, they look after the country and this is why their homeland means so much to them because it's a part of them. ${ }^{29}$

\section{'I didn't think of him as Japanese'}

While many Australians in the Occupation maintained a level of antipathy towards the Japanese, others managed to form positive relationships, exemplified by Shackcloth's earlier comment: 'In general I liked the Japanese people I got on very well with them.' Considering the climate in Australia at that time due to the effects of war propaganda, the experiences of POWs, and the fact that not long beforehand many Australian soldiers had been shooting to kill enemy Japanese soldiers in warfare, how did these changes come about? Such a comment was tantamount to heresy in Australia, and as Gerster has pointed out recently, one Australian newspaper ran a shocking headline in 1952: 'Our Soldiers Like the Japanese. ${ }^{30}$

In a recent casual conversation between myself and a BCOF veteran, ${ }^{31}$ he spoke of his affinity for many of the Japanese he met, and the difficulty he had relating this to other Australians when he returned from Japan. He explained to them that he 'didn't think of them as Japanese' - the label 'Japanese' had become tainted in Australia, associated with war, negative stereotypes and caricatures. To rise above such images, this soldier discarded that label - and instead came to view the Japanese as fellow human beings. Perhaps this is the real positive legacy of the occupation - a cross-cultural encounter that provided an opportunity to view each other's common humanity, in both its best and its worst forms.

\section{Conclusion}

The Allied Occupation of Japan constructed a space where cross-cultural exchange between Australians and Japanese occurred on an unprecedented scale. The exchange was largely driven by individuals rather than directed by the Australian government or the military, the latter instead imposing a 'non-fraternisation' policy intended to prevent

\footnotetext{
${ }^{29}$ Shackcloth, op. cit.

${ }^{30}$ Gerster, 'The Forgotten Veterans of World War II'.

${ }^{31}$ BCOF 'Kids' Reunion, Canberra, 5 March 2006.
} 
or reduce interaction. The stated aims of the Occupation were demilitarisation and democratisation, not the desire to gain a greater cultural understanding of each other. Considering the level of propaganda and images of cultural stereotypes that existed about the 'other' in both Australia and Japan before and during the Asia-Pacific war, the encounter proved to be more positive in many regards than may have been expected.

As in the case of Jin and Mitsuburo, memories of the Occupation are complex: sometimes fond, sometimes difficult; sometimes romanticised, sometimes exaggerated; sometimes clear, sometimes obscured by pain or time. The use of memories as an historical source is contentious, yet can give insight not only into the historical period under consideration, but its continuing legacy. This nexus of Australian and Japanese memories is the residual expression of the grassroots occupation experience; one that, despite stated allied or national aims at the time, proved to be a seminal cross-cultural opportunity for Australia and Japan, one that opened the path towards greater understanding and the development of positive relations.

\section{References}

Australian War Memorial (AWM) 114, 423/10/56 BCOF CSDIC Translations, 'Statement by Takemoto Masao', 8 September 1949 and 'Statement by Motoki Sukekazu', 7 September 1949.

AWM114, 423/10/56 BCOF CSDIC Translations, 'Reason for Resignation', 5 September 1949.

AWM52 8/2/33, 'BCOF Monthly Intelligence Review No. 20', November 1947, p. 2 (copy courtesy of Yoshida Takayoshi).

Gerster, R., 'The Forgotten Veterans of World War II', in The Age, 25 April 2006.

Helleur, D., Correspondence, 16 May 1999.

— Interview in Melbourne 1999.

Hungerford, T.A.G., A Knockabout with a Slouch Hat: An autobiographical collection 1942-1951 (Fremantle: Fremantle Arts Press, 1985).

—, T.A.G., Sowers of the Wind: a novel of the Occupation of Japan (Sydney: Pacific Books, 1961 (1958)).

Isogame, H., Interview in Etajima 2004, transcription translated by Okamoto Sota.

Joe [full name withheld on request], Letter, 8 November 1952, private collection, copy in possession of author.

Molasky, M.S., The American Occupation of Japan and Okinawa: Literature and Memory (London \& New York: Routledge, 2001).

Ōe, K., The Silent Cry: A Novel (Tokyo: Kodansha International, 1974). 
New Voices

Okamoto, K., Interview in Kure-shi 2004, transcription translated by Hirashima Mihoko.

Porter, H., A Handful of Pennies (Sydney: Angus and Robertson, 1958).

Matsuno, S., Interview in Kure-shi 2004, transcription translated by Hirashima Mihoko.

Tanaka, Y., Rape and War: The Japanese Experience (Clayton: Monash University Papers of the Japanese Studies Centre, 1995).

Watanabe, R., Tagawa, T. \& Masuoka, T. (eds), Hiroshima under Occupation: Anti-nuclear - Stories from the Early Hibakusha Movement, (senryōka no Hiroshima: hankaku - hibakusha undō sōsōki monogatari) (Tokorozawa: Nichiyosha, 1995).

_- Interview in Hiroshima-shi 2004, transcription translated by Hirashima Mihoko.

Yoshida, T., Interview in Kure-shi 2004. 